\title{
A training programme involving automatic self-transcending meditation in late-life depression: preliminary analysis of an ongoing randomised controlled trial - RETRACTION
}

Akshya Vasudev, Amanda Arena, Amer M. Burhan, Emily Ionson, Hussein Hirjee, Pramudith Maldeniya, Stephen Wetmore and Ronnie I. Newman

\section{Copyright and usage}

(C) The Royal College of Psychiatrists 2021. This is an Open Access article, distributed under the terms of the creative Commons Attribution-NonCommercial-NoDerivatives licence (http://creativecommons.org/licenses/by-nc-nd/4.0/), which permits non-commercial re-use, distribution, and reproduction in any medium, provided the original work is unaltered and is properly cited. The written permission of Cambridge University Press must be obtained for commercial re-use or in order to create a derivative work.

https://doi.org/10.1192/bjpo.bp.115.002394, Published by Cambridge University Press, 2 January 2018.

We, the Editors of BJPsych Open, have retracted the following article: Vasudev, A., Arena, A., Burhan, A. M., Ionson, E., Hirjee, H., Maldeniya, P., Wetmore, S. and Newman, R. I., BJPsych Open (2016), Cambridge University Press, 2(2), pp. 195-198. DOI: https://doi.org/10.1192/bjpo.bp.115.002394
The primary outcome measure listed in the trial protocol (NCT02149810) is change in heart rate variability. The primary outcome measure is not reported in this paper, the secondary outcome measure of depression severity is reported instead.

Additionally, the basis of this paper is a preliminary analysis of results. The preliminary analysis is not specified in the trial protocol.

\section{Reference}

Vasudev, A., Arena, A., Burhan, A., Ionson, E., Hirjee, H., Maldeniya, P., Wetmore, S. and Newman, R. (2016). A training programme involving automatic self-transcending meditation in late-life depression: Preliminary analysis of an ongoing randomised controlled trial. BJPsych Open, 2(2) 195-198. doi:10.1192/bjpo.bp.115.002394 